\title{
КОНЬЮГАТЫ ТАКРИНА С ПРОИЗВОДНЫМИ САЛИЦИЛОВОЙ КИСЛОТЫ - НОВЫЕ ПОТЕНЦИАЛЬНЫЕ МУЛЬТИТАРГЕТНЫЕ ПРЕПАРАТЫ ТЕРАПИИ БОЛЕЗНИ АЛЬЦГЕЙМЕРА
}

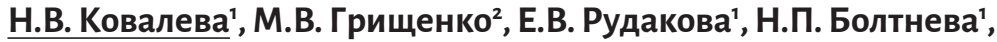 \\ Г.Ф. Махаева', Е.В. Щегольков ${ }^{2}$, Я.В. Бургарт ${ }^{2}$, В.И. Салоутин ${ }^{2}$ \\ ${ }^{1}$ Институт физиологически активных веществ РАН, \\ 142432, Россия, Черноголовка, Северный проезд, 1. \\ ${ }^{2}$ Институт органического синтеза им. И.Я. Постовского УрО РАН, \\ 620990, Россия, Екатеринбург, ул. С. Ковалевской/Академическая, 22/20.
}

DOI: 10.19163/MedChemRussia2021-2021-257

E-mail: kovalevanv@ipac.ac.ru

Одним из перспективных подходов к созданию мультитаргетных препаратов для терапии болезни Альцгеймера (БА) является объединение через спейсер двух фармакофоров, где в качестве одного из них используют известный антихолинэстеразный препарат. В плане сравнения свойств конъюгатов на основе отечественного препарата амиридина (A) и снятого с применения такрина (B) B качестве первого этапа в данной работе нами синтезированы гибридные соединения на основе такрина и производных салициловой кислоты - салициламида (C) и салицилальимина (D) $(n=2,4,6)$.<smiles>Nc1c2c(nc3c1CCC3)CCCC2</smiles>

12. A<smiles>Nc1c2c(nc3ccccc13)CCCC2</smiles>

13. $\mathrm{B}$<smiles>O=C(NCc1c2c(nc3ccccc13)CCCC2)c1ccccc1O</smiles>

14. C
11.<smiles>Oc1ccccc1C=NCNc1c2c(nc3ccccc13)CCCC2</smiles>

15. D

Исследование эстеразного профиля показало, что конъюгаты C и D эффективно ингибируют ацетил- (АХЭ) и бутирилхолинэстеразу (БХЭ) с преимущественным ингибированием БХЭ (ІС50БХЭ=10-20 нМ). Анти-АХЭ активность возрастает с увеличением длины спейсера и для соединений с $n=6,8$ превышает по активности такрин. Ингибирование карбоксилэстеразы достаточно слабое, т.е. не следует ожидать нежелательных лекарственных взаимодействий при терапевтическом применении данных конъюгатов. Конъюгаты ингибируют АХЭ и БХЭ по смешанному механизму и вытесняют пропидий из периферического анионного сайта АХЭ, при этом производные салицилальимина D существенно более активны (18-20\% при 20 мкM), что указывает на их способность блокировать АХЭ-индуцируемую агрегацию $\beta$-амилоида. Конъюгаты эффективно связывают свободные радикалы, более активны производные салициламида С (ТЕAC = 0.6-0.9). Таким образом, новые гибридные соединения сочетают в одной молекуле способность эффективно ингибировать холинэстеразы, связывать свободные радикалы и антиагрегантные свойства.

Работа выполнена при финансовой поддержке РФФИ, грант 19-53-26016а. 